\title{
Characteristics of Asphalt Concrete Using Retona Blend 55 as a Binder and Coal Fly Ash as a Filler
}

\author{
Anita Rahmawati $^{1 *}$, Emil Adly ${ }^{1}$, Romi Destiano ${ }^{1}$ \\ ${ }^{1}$ Department of Civil Engineering, Universitas Muhammadiyah Yogyakarta, Indonesia \\ *Corresponding author. Email: anitawidianti@umy.ac.id
}

\begin{abstract}
Buton asphalt is a natural resource owned by Indonesia. One of the Buton asphalt processed is Retona Blend 55 Asphalt. Due to the abundant stock and better quality, Retona Blend 55 Asphalt can substitute Pertamina asphalt. Besides buton asphalt, Indonesia also owns coal mostly used for steam power plants. Coal fly ash has a size passing sieve number 200 and a hydrophobic profile. Thus, the authors utilized coal fly ash as the filler in the concrete asphalt mixture and Retona Blend 55 as the binder. The experiment employed the Marshall method to determine the effect of using coal fly ash as the substitute material of several fillers. The test results obtained $6 \% \mathrm{KAO}$ with the filler application of 3\%, 3.5\%, 4\%, and $4.5 \%$, decreasing VMA, VIM, Marshall Quotient, and Stability. Moreover, the VFA, flow, and density values increased compared to testing without coal fly ash.
\end{abstract}

Keywords—Retona Blend 55, Coal Fly Ash, Asphalt Concrete

\section{INTRODUCTION}

In Indonesia deposits of rock asphalt found in many quantities in Buton Island, Southest Sulawesi, and named locally as Asbuton or Asphalt Buton. It is really dificult to produce material with consistently uniform, because many variation of rock deposit properties and composition[1]. When introduced under painstakingly controlled conditions, asphalt materials fusing Asbuton, have performed well, however as a rule, its exhibition on a more extensive scale, has been baffling. In particular, the service life of this material when used as road surfacing material or overlay was not equal to that achieved when conventional refinery bitumen was used, regardless of the type of mixture under consideration.

Asbuton has been used as a material granular for a base course in pavement layer in Indonesia. Asbuton is expected to be an alternative for asphalt material due to its massive amount, around 163 million tons [2].

Many types of Asbuton asphalt, such as Micro Asbuton, Mastic Asbuton, Buton Granular Asphalt, Retona, and Retona Blend, are produced by many agencies. Retona Blend 55 is a type of Asbuton asphalt produced by PT Olah Bumi Mandiri, which was first introduced in early 2000. It has the advantage of having high asphalt content compared to others. Utilization of Asbuton can increase the adhesiveness of asphalt to aggregates [3].

Asphalt (HRA), a mixture of type $\mathrm{C}$ and type $\mathrm{F}$, was used by Asbuton as a filler and fine aggregate, following the Specification of British Standard: BS 594 part 1-1985. The result of mixing HRA using the Marshall Test showed disclosed that the optimum asphalt content and Marshall Stability would decrease with Asbuton as a filler [4].

The stiffness of the material will increase with the addition of rock asphalt, and the potential for relaxation of the asphalt mixture at low temperatures will slightly decrease. The addition of rock asphalt increases material stiffness and slightly decreases the relaxation potential of asphalt mixture at low temperatures [5]. An increase in rocking asphalt content can increase the hydrophobicity of the asphalt mixtures [6].

Fillers are classified as fine materials that can modify the properties of asphalt binder and asphalt concrete mixtures. In this case, portland cement, hydrated lime, fly ash, limestone dust, and clay particles are considered fillers. The filler is not considered an aggregate part but a modifier to improve the durability and temperature susceptibility of the asphalt binder and the asphalt concrete mixture [7]. Apart from mineral utilization, fillers can increase the strength and stiffness of asphalt concrete [8].

This research aims to study the influence of coal fly ash as filler on the asphalt concrete wearing course mixtures with Asbuton (Retona Blend 55) as the binder. The contents of coal fly ash were varied in the asphalt concrete mixtures. The performance characteristics of the asphalt concrete wearing course mixture were tested using Marshall Testing Machine. The laboratory works were conducted in the laboratory of Universitas Muhammadiyah Yogyakarta. 


\section{MATERIALS AND TEST METHOD}

\subsection{Materials}

The asphalt used were Retona Blend 55 and extracted Asbuton from Buton Island. Table I displays the specifications adopted and the results of laboratory tests. It is shown that the properties of asphalt are relatively hard (Pen $40 \sim 50$ ).

Table I. Retona Blend 55 Specifications

\begin{tabular}{|c|c|c|}
\hline Type of Test & Specification & Result \\
\hline Softening Point $\left({ }^{\circ} \mathrm{C}\right)$ & Min $55^{\circ} \mathrm{C}$ & 55.25 \\
\hline Penetration $(0.1 \mathrm{~mm})$ & $40-50$ & 50 \\
\hline Specific Gravity & $1.05-1.15$ & 1.1 \\
\hline Ductility & $>50 \mathrm{~cm}$ & 166 \\
\hline
\end{tabular}

The fine aggregates and coarse aggregates used were crushed rock from Clereng, Kulon Progo Regency of Indonesia and the filler used were coal fly ash. The laboratory tests using Marshall Test Machine to analyze the properties of coarse and fine aggregates were: Los Angeles Abrasion, Adhesion with asphalt, water absorption and Specific Gravity. The result of the tests are presented in Table II and Table III.

Table II. Coarse aggregate specification and test result

\begin{tabular}{|c|c|c|c|}
\hline $\begin{array}{c}\text { Coarse Aggregate } \\
\text { Characteristic }\end{array}$ & Unit & Specification & Result \\
\hline $\begin{array}{c}\text { Los Angeles Abrasion } \\
\text { Test }\end{array}$ & $\%$ & $<40$ & 26,1 \\
\hline Adhesion with asphalt & $\%$ & $>95$ & 98 \\
\hline Water absorption & $\%$ & $<3$ & 1,66 \\
\hline Bulk specific gravity & $\mathrm{gr} / \mathrm{cm} 3$ & $>2.5$ & 2.56 \\
\hline Apparent specific gravity & $\mathrm{gr} / \mathrm{cm} 3$ & $>2.5$ & 2,60 \\
\hline Effective specific gravity & $\mathrm{gr} / \mathrm{cm} 3$ & $>2.5$ & 2,67 \\
\hline
\end{tabular}

Table III. Fine aggregate specification and test result

\begin{tabular}{|c|c|c|c|}
\hline $\begin{array}{c}\text { Fine Aggregate } \\
\text { Characteristic }\end{array}$ & Unit & Specification & Result \\
\hline Water absorption & $\%$ & $<3$ & 2 \\
\hline Bulk specific gravity & $\mathrm{gr} / \mathrm{cm} 3$ & $>2.5$ & 2.50 \\
\hline Apparent specific gravity & $\mathrm{gr} / \mathrm{cm} 3$ & $>2.5$ & 2.52 \\
\hline Effective specific gravity & $\mathrm{gr} / \mathrm{cm} 3$ & $>2.5$ & 2.62 \\
\hline
\end{tabular}

This study applied coal fly ash as the filler obtained from CV Lestari. The coal fly ash mixtures used were 3\%, 3.5\%, $4 \%$, and $4.5 \%$ of the filler weigh.

\subsection{Mix Design}

Design procedure of mixture using Marshall test ASTM D1559) was the manual to get the optimum asphalt content by weight of total mix. Three specimens at each asphalt (Retona Blend 55) content $(5 \%, 5.5 \%$ and 6\%) were tested for air flow, stability, voids in mineral aggregate, void in the mix, void filled asphalt and unit weight. The optimum asphalt content, which was the average of the asphalt contents that meet maximum unit weight, optimum stability and voids, was determined. Then prosentase of coal fly ash used in this reasearch were $3 \%, 3.5 \%, 4 \%$ and $4.5 \%$ of the weight of filler used.

\section{RESULT AND DISCUSSION}

\subsection{Marshall Test Result}

Parameters used to obtain Optimum Asphalt Content (OAC) of AC_WC mixture were Stability, Flow, Marshall Quotient (MQ), VIM, VMA and VFA. The samples to determine OAC were readied utilizing Asphalt Retona Blend 55 with going from $5.5 \%$ to $6.5 \%$ by weight, at $0.5 \%$ augmentation. The average weight of each sample was 1200 grams, compacted by $2 \times 75$ blows, and three samples were tested for each asphalt-content. The Marshall Test results are presented in Table IV.

Table IV. Marshall Test Result for Optimum Asphalt

Content

\begin{tabular}{|c|c|c|c|c|}
\hline \multirow{2}{*}{ Criteria } & \multirow{2}{*}{ Specification } & \multicolumn{3}{|c|}{ Asphalt Content } \\
\cline { 3 - 5 } & & $\mathbf{5 . 5 \%}$ & $\mathbf{6 \%}$ & $\mathbf{6 . 5 \%}$ \\
\hline Stability & Min $800 \mathrm{~kg}$ & 1630.57 & 1632.14 & 1626.33 \\
\hline Flow & $2-4$ & 3.83 & 2.54 & 4.07 \\
\hline MQ & Min $250 \mathrm{~kg} / \mathrm{mm}$ & 426.11 & 642.58 & 399.26 \\
\hline VIM & $3-5$ & 6.66 & 4.73 & 2.14 \\
\hline VMA & Min $15 \%$ & 17.82 & 17.08 & 15.79 \\
\hline VFA & Min $65 \%$ & 62.61 & 72.29 & 86.42 \\
\hline Density & - & 2.23 & 2.26 & 2.31 \\
\hline
\end{tabular}

The results of all the Marshall tests that were made on the asphalt and aggregates show the optimum asphalt content around $6 \%$ by weight of asphalt the optimum asphalt content without coal fly ash is $6 \%$. This ratio is obtained based on VFA, VMA, flow, stability, VIM at this asphalt content if its values are within the range specification in the region of the study. The results of Standard Marshall Test with $6 \%$ Retona and variation of coal fly ash ranging from $3 \%$ to 4.5 by weight of filler, at $0.5 \%$ increment are shown below.

Table 5. Marshall Test Result for With 6\% Retona Blend and Variation of Coal Fly Ash

\begin{tabular}{|c|c|c|c|c|c|c|}
\hline \multirow{2}{*}{ Criteria } & \multirow{2}{*}{$\begin{array}{c}\text { Speci- } \\
\text { fication }\end{array}$} & \multicolumn{5}{|c|}{ Coal Fly Ash Percentage } \\
\cline { 3 - 7 } & & $0 \%$ & $3 \%$ & $3.5 \%$ & $4 \%$ & $4.5 \%$ \\
\hline Stability & $>800 \mathrm{~kg}$ & 1632.1 & 1591.5 & 1498.5 & 1416.3 & 1470.3 \\
\hline Flow & $2-4$ & 2.54 & 3.37 & 3.10 & 2.88 & 3.38 \\
\hline MQ & $\begin{array}{c}>250 \\
\mathrm{~kg} / \mathrm{mm}\end{array}$ & 642.58 & 472.72 & 483.27 & 491.19 & 491.19 \\
\hline VIM & $3-5$ & 4.73 & 3.17 & 3.17 & 2.85 & 1.78 \\
\hline VMA & $>15 \%$ & 17.08 & 15.72 & 15.72 & 15.44 & 14.51 \\
\hline VFA & $>65 \%$ & 72.29 & 79.82 & 79.83 & 81.56 & 87.75 \\
\hline Density & - & 2.26 & 2.30 & 2.30 & 2.31 & 2.33 \\
\hline
\end{tabular}




\subsubsection{Marshall Stability}

Stability is an ability of pavement layers receives the load traffic without permanent deformation such as, rutting. The value of stability influenced by asphalt cohesion, the asphalt content, internal friction, the nature of interlocking of aggregate particles, shape and texture surface and aggregate gradations. The testing suggests that the stability obtained tend to decrease by adding coal fly ash filler content. Stability test result was shown in Fig. 1.

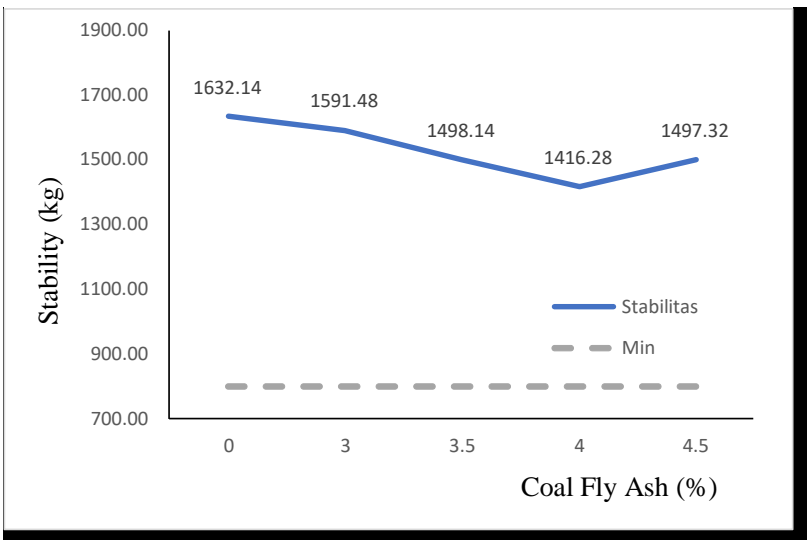

Fig. 1. Fig. 1. Stability test result with coal fly ash

The stability test results are shown in Fig. 1. The results disclose that the stability decreases with the increase in coal fly ash content up to optimum and then increases. The optimum coal fly ash content was found to be $4 \%$. In short, the stability values met the specification of not less than $800 \mathrm{~kg}$. The results indicate that the asphalt mixture using Retona Blend 55 with coal fly ash has lower stability than without coal fly ash. The decrease in stability can be attributed to decreased adhesion between the aggregate and Retona Blend 55 asphalt.

\subsubsection{Marshall Flow}

Fig. 2 depicts the flow test results, implying that the flow decreases with the increase in coal fly ash content. In other words, flow values met the specification of within range 2 to 4 . The decrease of flow indicates that the mixture has insufficient asphalt content and becomes stiffer. Previous research stated that increasing the percentage of coal fly ash used as a binder can reduce Marshall Flow [9].

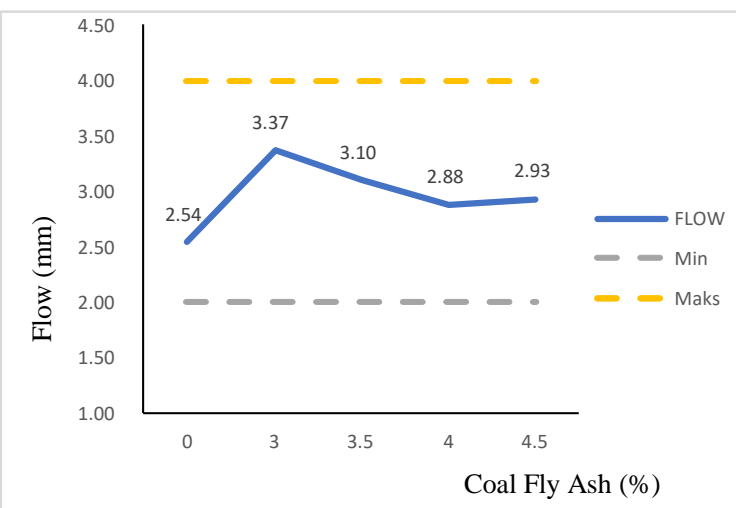

Fig. 2. Flow test result with coal fly ash

\subsubsection{Marshall Quotient}

Marshall Quotient (MQ), the ratio of stability and flow, indicates the quality and strength of asphalt mixture. The higher MQ value indicates that the asphalt mixture has more stiffness and strength to cracking. Hence, the asphalt mixture is more resistant to permanent deformation. It also signifies that the higher the coal fly ash content, the MQ tends to increase. MQ test result can be seen in Fig. 3.

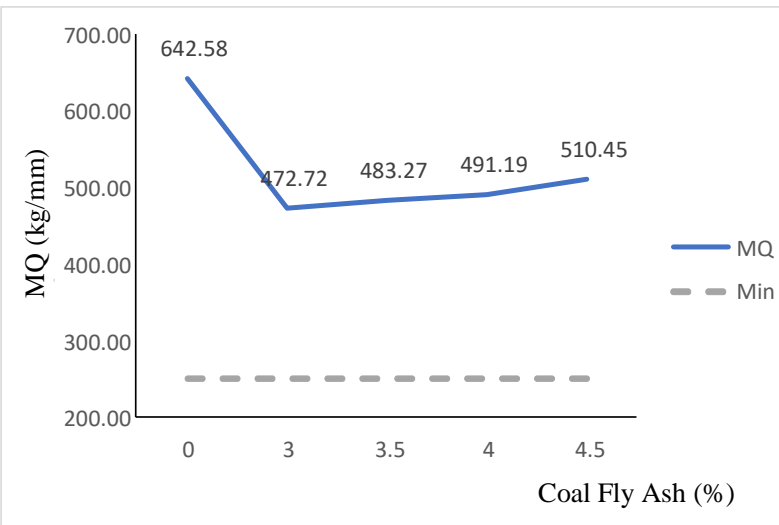

Fig. 3. MQ test result with coal fly ash

\subsubsection{Void in the Mix}

Fig. 4 demonstrates the void in the mixture (VITM) test results, uncovering that the VITM decreases with the increase in coal fly ash content. Therefore, the VITM values with 3 and $3.5 \%$ of coal fly ash met the specification of not less than 3 . The results indicate that the asphalt mixture using Retona Blend 55 with coal fly ash has lower VITM than without coal fly ash. The decrease of VITM indicates that the void in the mixture can be filled with coal fly ash. The decrease in VITM, along with the increase in coal fly ash content, was also found in previous research [10].

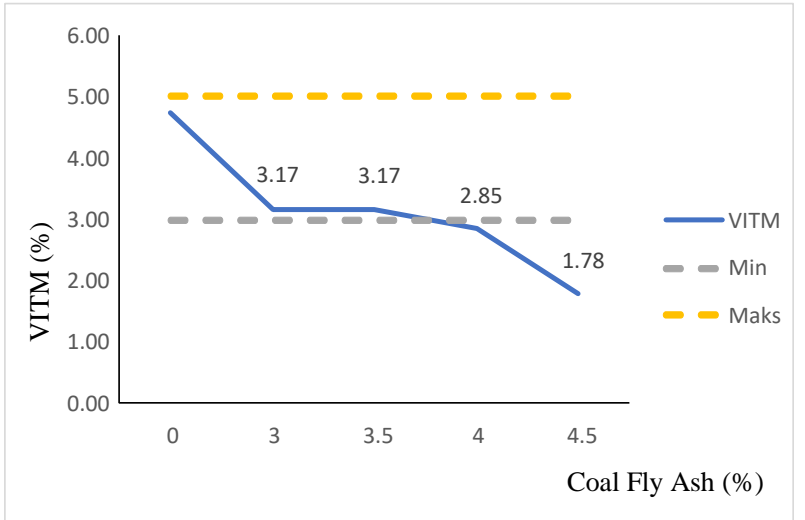

Fig. 2. Fig. 4. VITM test result with coal fly ash

\subsubsection{Void in Mineral Aggregate (VMA)}

Fig. 5 displays the void in mineral aggregate (VMA) test results, showing that the VMA decreases with the increase 
in coal fly ash content. It can be seen that the VMA values with $3 \%, 3.5 \%$, and $4 \%$ of coal fly ash met the specification of not less than $15 \%$. The results indicate that the asphalt mixture using Retona Blend 55 with coal fly ash has lower VMA values than without coal fly ash. The lower VMA signifies that less space is available for the asphalt film; however, a durable asphalt mixture requires an adequate asphalt film thickness. The analysis results revealed that the higher the coal fly ash content in the mixture resulted in a lower VMA value because the cavities in the aggregate would be filled with coal fly ash as binder material.

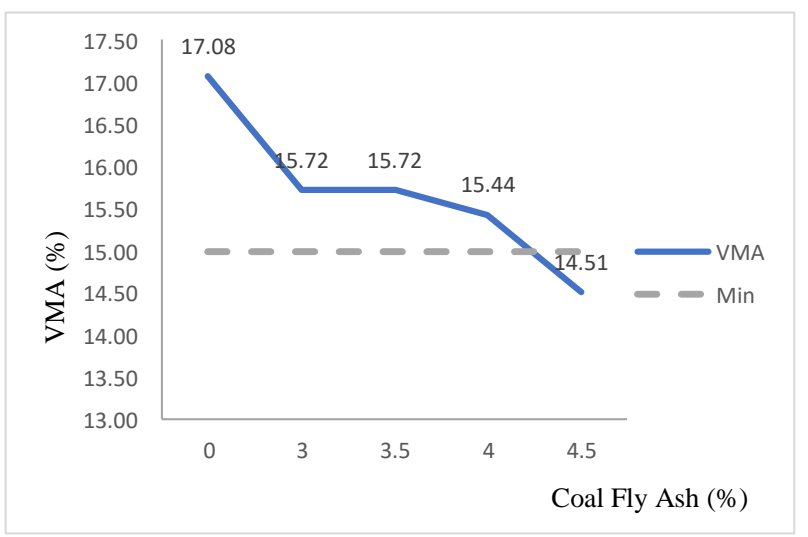

Fig. 3. Fig. 5. VMA test result with coal fly ash

\subsubsection{Void Filled Asphalt (VFA)}

The increase in coal fly ash increased the voids filled with asphalt (VFA).VFA is the voids in mineral aggregates filled with asphalt. The increase in VFA indicated an increase in the effective asphalt film thickness, resulting in higher durability of asphalt mixture. VFA test result can be seen in Fig. 6.

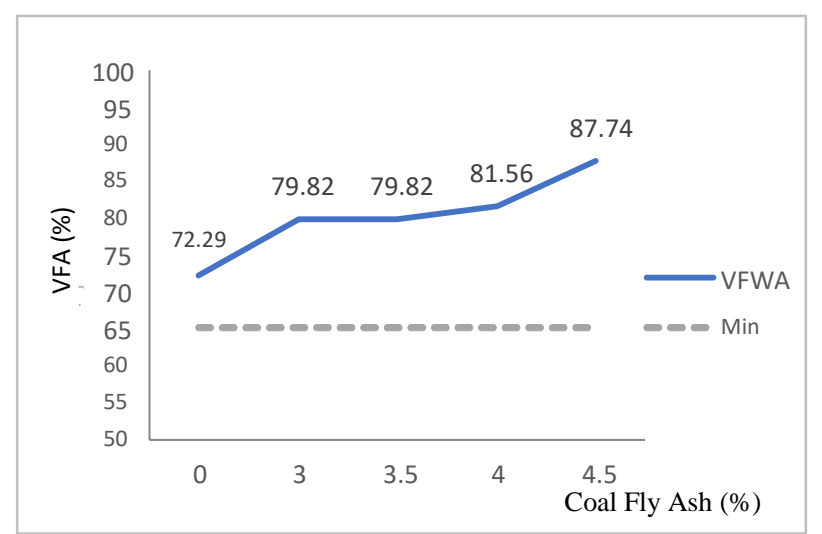

Fig. 6. VFA test result with coal fly ash

\section{CONCLUSION}

The research results revealed that the modified mixture using Retona Blend 55 as a binder and coal fly ash as filler tended to decrease stability, flow, void in the mixture, and void in mineral aggregate. Conversely, the void values filled with asphalt and Marshall Quotient values were likely to increase.

Overall, the use of Retona Blend 55 as a binder and coal fly ash as filler provided excellent performance, particularly in terms of greater resistance to permanent deformation.

\section{REFERENCES}

[1] J.McElvaney, Characteristics of Asbuton and AsbutonAggregate Mixtures. in Pasca Sarjana Workshop, Bandung, Indonesia.(1988)

[2] A.Kawakami, I. Sasaki, K.Kubo, S.Ueno, M. Hermadia and W. Pravianto, Possibility to Utilize New Natural Rock Asphalt for Guss Asphalt, JapanIndonesia Cooperation on the Research in AsButon, Asphalt pavement, Volume 2, (2014)

[3] M. Hermadi, and Kurniadji, Utilizatin of Asbuton As An Anti Stripping Agent of Asphalt Pavement, 1st IRF Asia Regional Congress Paper Submission Form November 17-19, Bali, Indonesia (2014)

[4] B.S. Subagio, B. Siswosoebrotho, and R. Karsaman. Development of laboratory performance of indonesia rock asphalt (ASBUTON) in hot rolled asphalt mix. in Proceeding of the Eastern Asia Society for Transportation Studies. Citeseer (2003).

[5] R. Li, P. Karki and P. Hao , Rheological and low temperature properties of asphalt composites containing rock asphalts. Construction and Building Materials, Elsevier, 96: p. 47-54. (2015).

[6] L. Jing, G. Xiaoxuan, J. Yuzhao, B. Niuniu, L. Yu, and W. Chuanghaig, A micro-analysis of Buton rock asphalt.. Journal of Computational and Theoretical Nanoscience, 12(9): p. 2751-2756. (2015)

[7] C. Gorkem, and B. Sengoz. Materials, Predicting stripping and moisture induced damage of asphalt concrete prepared with polymer modified bitumen and hydrated lime. Construction and Building Materials, Elsevier, 23(6): p. 2227-2236. (2009).

[8] A.H. Aljassar, S. Metwali, and M. Ali, Effect of filler types on Marshall stability and retained strength of asphalt concrete. International Journal of Pavement Engineering. 5(1): p. 47-51.(2004)

[9] A. Taher, "Characteristics of Asphalt Concrete Mixture (AC-WC) with Variation of Fly Ash Filler from Coal" [Karakteristik Campuran Beton Aspal (AC-WC) dengan Menggunakan Variasi Kadar Filler Abu Terbang Batu Bara], SMARTek, 7 (4): p. 256 - 278. (2009)

[10]. M. Z. Arifin, M. Sadillah \& A. Wicaksono. "The Effect of Fly Ash Coal Application as Filler to Resilient Modulus of Surface Layer of Asphalt Concrete" \{Pengaruh Penggunaan Abu Terbang Batubara sebagai Bahan Pengisi terhadap Modulus Resilien Beton Aspal Lapis Aus \}, Jurnal HPJI, 4 (1), p : 59-66. (2018). 